\title{
Thematic Fields, Transgressive Religion: Disembodiment and the Will to Nothingness in "Safe Haven."
}

\author{
Adam Lovasz
}

The demon appears as the spirit of the negative which, through all the avatars of man, preserves his power and keeps his quality. He stands for the will to nothingness which makes use of man as a reactive being which gets itself carried by him but which, at the same time, does not fuse with him and 'jumps over' (Deleuze 191).

A dark light illuminates the remorseless eyes of the seeker. What does the dark light of remembrance seek to convey? And through what mediations must the illness that is recognition pass through before it may infect the viewers of this sorry spectacle? These and other such questions proliferate in us while viewing the found footage horror anthology, V/H/S 2. Scenes of anguish, sexual excitement, spatiotemporal distortions and monstrous transformations abound throughout the various segments. Among the installments in V/H/S 2, many of which have spawned commentaries in secondary literature, and will undoubtedly continue to do so in the future as the literature on the found footage subgenre grows, one segment in particular stands out: "Safe Haven", directed by Timo Tjahjanto and Gareth Huw Evans. This work constitutes much more than the debut of these two young filmmakers. It is my contention that "Safe Haven" is a sovereign work that penetrates the boundaries of a genre that is predicated upon a paradoxical restriction of viewpoints. As Neil McRobert has noted in relation to found footage films, "point of view is restricted, which matters in such faux-realist cinema, as the lack of access to knowledge is a major part of the terror for both the protagonist and the viewer" (McRobert 143). 


\section{IJCS}

In the case of "Safe Haven", lack of knowledge is not an epistemological issue. Rather, we as viewers are treated to an excessive, transgressive experience that cannot be translated into anything remotely intelligible. Instead of a lack, what we have here is an excess of knowledge so explosive that it violently shatters the coherence of the narrative. Hence, it is impossible to make sense of the events portrayed in the segment through the utilization of a linear narrative. Rather, it is my contention that one must approach the transgressive nature of "Safe Haven" through an interpretative model that highlights the role of amorphous atmospheres in horror film viewership, as opposed to discrete perceptions. My use of Aron Gurwitsch's notion of "thematic fields" serves precisely this purpose. My argument is that "Safe Haven" introduces, through its overmediation of unrepresentable spiritual phenomena, a thematic field into the consciousness of viewers that is open to the most abyssal possibilities of religiosity. This thematic field exhausts representation, until the latter is evacuated of all intelligibility. What we learn is that the integrity of the subject cannot survive the encounter with abyssal knowledge, as transmitted through handheld cameras.

Technologically mediated representation can only capture a small portion of existential anxiety. At the commencement of "Safe Haven", we find a film crew making a documentary about an apparently controversial Indonesian sect. Travelling to the compound of this odd religious community, the film crew interview the cult leader in his office. In the film, we see seated in front of the camera an improbable figure dressed in white, somebody revealed to be the leader of the bizarre millenarian sect. Troublingly, his words contain something sinister, a premonition as it were, pointing towards realms far beyond custom, tradition and conventionally codified knowledge. As opposed to the interviewers, connected as they are in the manner of cyborgs to technologies of representation, he recognizes that "all you see before you, is temporary" and "there is a higher order, another plane of existence." Just what this plane of existence is, and how it relates to broader issues of genre and media realities, is revealed in all too graphic fashion as the segment careens to its preposterous end. But first, we must identify the environment in which consciousness, mediated consciousness included, is situated. Kjetil Rødje has rightly highlighted the importance of cameras in foundfootage films as not merely passive technologies of representation, but also as sources of agency that become progressively more independent of their ostensible human masters. Rødje summarizes the fundamental premise of the found-footage horror genre in the following: "no one is left alive. Only the footage remains, and only the footage can tell what may have happened" (Rødje 207). This premise may be transformed into a double imperative of sorts, a categorical sorting device that can be of help in selecting authentic representatives of the genre: a) in the case of a found footage film, every human character must die. It is the limitlessness of death afforded by the first sub-component of the double imperative that allows for the second sub-component: b) in as much as each and 
every human character has perished, only the footage may remain. But can the footage ever do full justice to all that happened?

One could make the argument that found footage is not a genre, but rather nothing more than a method of framing (Reyes 124). Plane and frame are, in spite of their media theoretical applicability, inherently spatial categories. Prior to elucidating the multiplicity of planes in "Safe Haven", it will be helpful to introduce a concept of psychology that is relatively unknown today, namely Aron Gurwitsch's idea of the "thematic field." While there is little scope within this paper to fully unpack the implications of Gurwitsch's phenomenologically inspired psychology, I do not wish to utilize this concept in a merely psychological manner. Instead, I seek to borrow the concept of "thematic field", separate it from its background and reuse it as a media theoretical term. Such a misappropriation may appear problematic, and it is far from simple to identify why, of all concepts, we should use this particular one. Consciousness, including that affected by horror films or horrific effects, does not enact itself in empty space. Rather, consciousness is undergirded by "invariants of consciousness", a term Gurwitsch borrows from William James (Gurwitsch 311). The objects represented to consciousness appear in contexts, invariant structures that are mind-independent even in the case of prehended existents. This latter point is especially pertinent with regards to film philosophy and media theory, for it also implies that perceived events, even fictional ones, are mind-independent.

Prehended events, in spite of their correlation with consciousness, are nevertheless fully objective. The awful fate of a protagonist in a horror film affects us as viewers because this terrible scene has a presence of its own. Presence is awe-inspiring. Themes, defined as objects capable of presenting themselves to a perceiving agent, always come with fields attached to them. They are never entirely sealed entities, but rather contextual enactments. We choose our own themes (312). This apparently free "choice", however, is always already constrained by the material contents of both field and theme (311-2). Although they choose the genres which fit their own interests, even the most reflexive of viewers is affected by a broader context. Allure is contextual, and depends upon a field already overlayed by a range of factors. It is the broader contexture that announces itself through a theme that seems to stand out from its background. So exciting is the theme that it can even free itself of its background. Preternatural events are such instances; they are themes whose otherworldliness separates them from any believable phenomenal background. Otherworldliness is independent of verification, hence the alluring nature of even fictional supernatural events. The unnatural cannot be reintegrated into nature, the supernatural event, the advent, cannot be shoved back into everyday banality. Events in general are disconnections, emanating encoded distress signals that operate through strange spatiotemporal loops. Time sits buried within innumerable far-off places, until the event sets it loose among the multiplicity of fields. 


\section{$38 \quad I J C S$}

A theme, in as much as it is given, is never given in its entirety to any agent. No representation can exhaust the excess contained within a certain theme. In the case of the horror segment under discussion, Indonesia as an imaginary field represents an inexhaustible location of warm exoticism, juxtaposed against the cold, Western rationality and skepticism of the camera crew. True, the dichotomy between a supposedly irrational East and a rational, disenchanted West smacks of Orientalism, even in cases when the East is represented as superior to Occidental culture (Said). "Safe Haven" avoids the pitfalls of Orientalist representation by skillfully decentering the focus from human themes, as we shall see shifting focus from the human world to another dimension. Arrogantly and unjustifiably, the camera crew believes that their cynical search for good TV content can continue in perpetuity, whereas the cult leader already knows that all themes are fleeting. In this sense we could easily get the mistaken impression that the Indonesian exotic Other knows more than anything the Western gaze can comprehend. But the cult leader himself is but a mere pawn of nonhuman forces. Fields only have relevance in relation to themes.

But the proliferation of themes is an infinite process. As Gurwitsch puts it,

the appearance of a theme must be described as emergence from a field in which the theme is located occupying the center so that the field forms a background with respect to the theme. The theme carries a field along with it so as not to appear and be present to consciousness except as being in, and pointing to, the field (311).

From a human-centered narrative of culture shock emerges a profoundly nonhuman story of mutation that tears apart human narratives. Emergence is, by definition, a perspectival and open process, a limitless, vertiginous movement. Themes are not restricted to any one perceiver. When the characters themselves are represented by their ubiquitous cameras, they themselves become fields carried away by themes far beyond their control. Demons operate precisely in this manner, arriving from above, plucking away unfortunate souls, plunging them into unspeakable damnation. Saint Augustine states that demons "are animals of the air" (Elliott 130). Angels are originally composed of ethereal, pure air, but sin transfers them to a corrupted field, the field of damnation. "With the advent of sin", demonic corporeality is "drawn from the lower, gloomier air." (ibid) The demonic is a theme of paramount importance in "Safe Haven." But not all themes are created equal; for every theme that presents itself in a distinct, clear manner, there are multitudes of gloomy, impure themes, characterized by a tendency to "blend and melt into" one another (Gurwitsch 327). Although I would refrain from a detailed cultural historical investigation, we have every reason to connect indetermination with the demonic. Impurity, as for instance in the case of menstruation, is portrayed by one medieval European commentator as a gateway allowing for the invasion of the visible realm by demonic forces (Elliott 108). 
Pure demoniac infection is constituted by absolute impurity, complete indeterminacy: "vagueness, indistinctness, indetermination may be almost complete" (Gurwitsch 327). In some cases, the field is fully capable of melting into the theme upon whose coattails it traverses the universe. Such a framing, of course, can lend itself to problematic inferences. Too often, throughout various cultures, women have been equated with impurity. Menstruation and childbirth in particular lend themselves to culturally coded misogynistic equations with pollution. The feminine, in misogynistic discourses, becomes a horrific power that infects everything in its environment, proliferating abjection, dirtying the social body with its menstrual effluence (Kristeva).

The thematic field, being the contexture that organizes itself around a theme, is far from unmodifiable. In fact, Gurwitsch argues for the modifiability of the field, as opposed to the static nature of the theme. While both "field" and "theme" are intended by Gurwitch to be purely phenomenological and descriptive terms, ideas pertaining to experience, I see no difficulty in ontologizing these categories. In relation to its field, a theme is metastable. If nomadism constitutes the prime modality of the field, then sedentary Being constitutes the modality of the theme. However, I would argue that nomadism cannot be restricted to an either/or choice between field/theme. Indeterminacy does not allow for a fixed, stable boundary separating fields from themes. In the case of demonic proliferation, fields become themes in their own right, violently foregrounding themselves. Evan Calder Williams, writing on the broader horror genre, has drawn attention to "the way content gets swallowed by the depth of the field" in depictions of apparently senseless violence (Williams 32). Here I see a connection between horror aesthetics and field psychology that may be productively exploited in the interest of philosophical experimentation. As opposed to content, Williams argues for the foregrounding of "horrible form", background elements that ordinarily reside underneath narrative, but occasionally burst up from their subterranean depths. Horrible form is "secondary material that refuses to quit the scene", a remainder whose awfulness resides in its very refusal to disappear (33).

Yet, as distinct from Williams, I would argue here for a dynamic depiction of the field that sucks content into itself. "Safe Haven" is full of such movements, both discursive and literal. It is not enough to merely foreground the rather bland materiality of the cult's compound. In and of itself, this field does not yield the full complexity of the horrible form we are after. What is more interesting is the nomadic transubstantiation of themes into fields and vice versa. Similarly to other segments of the $\mathrm{V} / \mathrm{H} / \mathrm{S} /$ series, seemingly irrelevant details and plot elements take on unexpected significance. In "Safe Haven," all that we see in front of us is temporary - the frame itself included. Without a clear separation between field and theme, chaos awaits the viewer. From the beginning of "Safe Haven," it quickly becomes apparent that this will prove to be no ordinary documentary film, for there is too much detail involved. This is a documentary film that obviously 


\section{IJCS}

never made it to the final cut. For instance, Malik, a reporter and head of the crew, overhears his fianceé Lena, also a member of the journalist team, saying that she is pregnant with somebody else's child - surely, a scene far too authentic and spontaneous for television! Again and again, we see the feminine equated with unexpected events, excessive moments and pollutive aspects. It is as though all of Lena's actions represented a threat to the framing of this program as a documentary. As Julia Kristeva has shown, "corporeal waste (...) represents a threat to the symbolic order" (Kristeva 1982: 70). Ironically, through the course of the film, it is Lena's unwillingness to abort - and hence "waste" - her illegitimate child that complicates the plot, polluting the narrative with an excess that should never have come into existence...

Another important characteristic of the found footage subgenre or style, is its abandonment of the cinematic frame. We are falsely led to believe that this footage has been somehow uncovered, retrieved through subterfuge or sheer daring. Even in the case of the cinematic, edited frame, we can speak of a territoriality "as incapable of containing what exists within its territory as it is of protecting it from the invasion of what lies beyond its borders" (Sayad 49). Just as Lena is incapable of containing her unusual progeny, or the truth of her pregnancy, so the camera proves incapable of keeping excess within the frame. Cameras, in found footage films, fail to provide even the minimal protection that cinematic frames do. Sayad identities found footage films as reflexive transgressions of frame. One interesting aspect of this disturbing destabilization is the role of camerawork in producing such an atmosphere of fatal realism. In the case of found footage horror, "borders are made unstable by the shakiness of handheld shots, abrupt zooms, and swish pans that do not seamlessly rest on an object, requiring constant adjustments in focus and in the positioning of the camera. In fact, these stylistic features suggest not borders but their opposite: the frame's inability to contain what lies within its territory" (55). Instead of demarcation, in the found footage genre the deconstructed frame serves to make the bodies and minds of viewers even more fuzzy, porous, open to infectious hauntings. This is the degree zero of cinema, the implosion of content through the multiplication of horrible forms, badly written improvised scripts and deliberately substandard camerawork. Similarly to Paranormal Activity, we see in "Safe Haven" the use of both static and handheld cameras (Rødje: 212). But this apparent dialectical opposition is a false one, because even the mounted camera is disturbed, knocked over during the course of the segment's tumultuous events. Proceeding further inward, in the direction of the pollutive secrets that the camera crew seek to expose in the manner of colonial explorers, the crew begins to realize that the availability of themes always exceeds the ability to record these variegated forms. Ordinarily, a documentary is crowned by some achievement, for instance the debunking of a false prophet. We are led to assume that the cultleader is simply another False Messiah, whose empty messages serve his own enrichment. Alas, reality is too real. 
The first explicit sign that something is amiss occurs when the crew realizes that their batteries are low on power. Such a banal technical malfunction puts an end to the ambition of Enlightenment. Transparency, it would seem, shall not triumph after all. Shakiness is a condition by no means restricted to the handling of the camera: a theme can connect itself to several different fields. For example, the theme of unsteadiness can feed into psychic and physical fields alike, spreading its infection across various media and contents. Enclosed upon itself, content would wither and die. Without exposure to the Outside, the necessarily fuzzy boundaries of the viewer's body and the journalist's gaze would attain a pale, ghostly quality that is, interestingly, lacking in this story. The tropicality of the Indonesian setting precludes Northern Gothic coldness. Thematic fields connecting to a theme need not have anything in common, with the exception of their common theme (Gurwitsch 314). In Gurwitsch's approach, the theme is a nucleus around which various fields circulate. Playing with the possibilities of intermediality, we may even say that the camera, as the locus of a heterogeneous assemblage of fields, could very well constitute a theme. But we can equally say this of Adam and Lena's transgressive extramarital fornication. Evil little thoughts start to insinuate themselves into our own consciousness. But even stronger is the malignant thought: who cares about Lena and her love triangle? This would surely be an instance of a "horrible form", an uninteresting background feature of an otherwise riveting, exotically "Oriental" Southeast Asian postcolonial landscape.

But Lena's pregnancy shall prove a great deal more unpleasant than we could ever have anticipated. It has nothing to do with any kind of empowerment or free choice. In this narrative, all human protagonists are marionette puppets of deeper, occult forces. Prior to elucidating the emergence of the demonic, we must underline the following injunction: "the thematic field must be taken exactly as actually experienced and only as it presents itself in the given case" (321). Experience itself is primary, yet only those entities may become objects of experience that give themselves to contact. There is no question here of human agency enjoying any primacy with regard to the object of a thematic field. Following Rødje it is important to note that even seemingly inanimate objects "experience" their surroundings, in the sense that most entities contain some level of responsiveness. In most found footage films, "the camera liberates itself from being a tool under human control" (Rødje: 219). "Safe Haven" proves no exception. As a consequence of the camera being endowed with agency, the diegetic camera can be said to have thematic fields of its own. Gurwitsch's model can hence be adapted to representational technologies freed of their subservience to human masters. Fields endlessly supersede one another, in an infinite regress that can never be closed permanently. However far mediations may descend into zones of human weakness or disgusting double-dealing, there are internal territories that remain obscure even before the gaze of cold, lifeless technology. 


\section{IJCS}

There is only so much that may be done with a camera - there is only so much a camera may do. Lena's duplicity is also evinced by her acceptance of a pendant given to her by a girl, evidently sexually initiated by the pedophile cult-leader, only to throw away the religious object in aversion. Her aversion is directed at this apparent superstition, as well as what she perceives as the "creepy" nature of religion. Even the most diffuse, the most obscure of fields is "tinged in a specific manner" (Gurwitsch 328). This tinge, in the case of the Indonesian cult, seems to be an overwhelming negativity, a negation that has not yet arrived, a darkening of the phenomenal horizon whose contours can barely be made out. We feel there is something sinister about the cult compound even before anything out of the ordinary has happened, but cannot quite put our fingers on what this could be. Instead of an uplifting, light, spiritual atmosphere, we find an unpleasant climate not unlike that of an abattoir or an industrial building, a warehouse filled with evil little thoughts, hints of pedophilia sprinkled with incest, prereflective perceptions, and a fanaticism of uncertain origin. The cult-leader is adamant in his assertion that the gate he seeks to open is located in the real world, and most certainly not in some kind of transcendent dimension.

Indifference, defined as the inner decay of difference among the elements of the field, is an infectious, dangerous, virulent system that does not leave any thematic field intact. Elements are subject to a corrosion working its way out of each and every participant in this macabre theatre: "no thematic field is entirely unaffected by indistinctness" (329). This feature may also be grasped in the uniformity of the students. Rather rudely, while Malik is interviewing the cultleader, Lena intrudes upon a classroom, only to be confronted by one of the teachers, who exclaims: "Beautiful, aren't they?" (referring to the young students) "but not as beautiful as yours will be." This unpleasant moment is a masterpiece of allusion. How could the sect's members know about Lena's pregnancy? Is it just a culturally coded stereotypical assumption that she will, sooner or later, at some point in time, give birth? Infirmity, above all else, is the breeding-ground for demonic infection. Already, Lena's pregnancy is tinged by some unspeakable, ungraspable, obscure negativity. Kristeva identifies the power of pollution with the latent threat of an "unsettled separation between masculine and feminine power" (Kristeva 78). Sullied by her unfaithfulness, Lena is pushed further into doubt by her bizarre encounter with the schoolteacher complimenting her unborn child. Items within a thematic field are capable of blending, melting into one another. Lena's unfaithfulness blends with socio-cultural assumptions relating to the role of woman-as-mother. As we learn later, Lena intends to "keep" her child, as opposed to Adam's entreaty to consider abortion.

Like some huge tomb, the plot opens up to negation, slowly but ever more heavily. Vagueness and indistinctness, when referred back to their original contextures, are exposed as features of negativity, passivity and endurance. That which is indistinct must endure its inability to become differentiated. At this point, it will be interesting to explore further the thematic field that I denote 
"transgressive spirituality." Within transgressive spirituality, there resides pure negativity, a negation so complete as to suicide itself into the celestial state of anguish and fright. This form of religion, in actuality, lends credence to Friedrich Nietzsche's otherwise rather far-fetched claims relating to the negativity of religiosity in general. If we utilize the Nietzschean view on religion as being the quintessential embodiment of the "will to nothingness", and take it as a reference to transgressive spirituality, we can bring more theoretical depth to our discussion of the many fields of negativity eating their way through the plot of "Safe Haven." In a very engaging and polemical passage, Nietzsche writes:

With the priests everything becomes more dangerous, not only cures and remedies, but also arrogance, revenge, acuteness, profligacy, love, lust to rule, virtue, disease - but it is only fair to add that it was on the soil of this essentially dangerous form of human existence, the priestly form, that man first became an interesting animal, that only here did the human soul in a higher sense acquire depth and become evil - and these are the two basic respects in which man has hitherto been superior to other beasts! (Nietzsche 32-3).

Whether this truly makes the soul sickened by religion "superior to other beasts", be they animals or demons, is debatable. But from this sweeping condemnation of all existing religious forms, we can extract the idea of the "priest" as denoting any transgressive agent who tends to make "everything dangerous". The priest, for Nietzsche, is a disgusting creature who sickens the will to live, equated here with the will to power. Priests sublimate otherwise healthy, life affirming drives into self-hatred, weakness and passivity. Religion replaces the will to power with the will to nothingness (32). Similarly, underneath the egalitarian Hegelianism of Dühring and, by extension, egalitarian political projects in general, Nietzsche identifies almost exactly the same tendency, a weariness of life and an aversion to suffering that slips into the affirmation of nothingness, "a principle hostile to life, an agent of the dissolution and destruction of man, an attempt to assassinate the future of man, a sign of weariness, a secret path to nothingness" (76). If, against Nietzsche's wishes, we clean this description of its negative residue, we find an apt description of transgressive spiritual practices, including those that fail to reproduce their adherents. The key criteria, after all, of any religion's long-term evolutionary success is the reproduction of its followers. Without reproduction, the flock cannot persist, belief abates and ruination awaits the religious community. Therefore, the will to nothingness must be kept at a reasonable level. In modernity, Nietzsche sees the arrival of a form of spiritual decay that untethers the "will to nothingness", "the great nausea" (96). Complete irreligiosity allows for a will to nothingness unleashed from all metaphysical principles. Henceforth, the will to nothingness remains in its pure state, freely corroding all of society until humans become extinct, swallowed up by the void of meaninglessness. 


\section{IJCS}

My suggestion is that, parting ways with Nietzsche, we learn to see the liberating aspect of this apparently total negation. The cult-leader portrayed in "Safe Haven" is a Nietzschean priest who sickens all he touches. However distasteful it may seem, there is something sovereign in his insanity. He believes he is right - and is proven right in the end by events clearly beyond the control of any human protagonists. Driving his flock to the "great nausea" and beyond, the leader clearly enjoys the abyss he has unleashed. Inexplicably, the cult proceeds to commit collective suicide. Religion proves to be nothing more than the secret path to nothingness, the way leading to annihilation. Asceticism is opposed to life. The shrieks of the reporters betray a perception that is alien to the thematic field they find themselves embedded in. Ironically, this also constitutes a case of reporting becoming far too embedded. Since the Gulf War, "embedded reporting" has become synonymous with a style of reportage that purports to show history in motion, history as it is happening. In the case of the fictional suicidal cult compound, the event overshadows the media through which it should multiply. Profane individuals cannot understand the logic of sacred asceticism, spirituality that nears the stage of complete dissipation. Even in its germinal form, spirituality is contaminated by the will to nothingness, a circumstance brilliantly captured by Nietzsche's genealogy. In religion, the body becomes a tenant of death, an exposed, naked, brute corporeality that may be tossed out into the street with abandon as soon as it fails to pay its dues. In the ascetic mode of wearied life seeking out, in startling fashion, voluntary death, life still needs a goal, for "it will rather will nothingness than not will" (97). At the limit of mediation, the real fails to be contained within the frame. Centripetal forces are enacted by the frightening autonomy of heterogeneous objects and entities that were formerly presented to the viewer as being inconsequential.

While the frame is "centripetal", Andre Bazin characterizes the screen as being "centrifugal" (Bazin 166). The screen decenters the image, making it limitless. By consequence, we lose the ability to orient ourselves in the demented thematic field. We need not restrict this state of disorientation to the incontinence of visual content in film, for in the case of other forms of perception also, a similar destabilization may be observed. Inner experience is the pitiless abandonment of similitude, in favor of an insatiable mimetic proliferation of difference. When cinema integrates an existing artform, this encapsulation must be understood as the gifting of a new mode of existence. Cinema neither serves nor betrays (168). The handheld camera gifts a mystical experience, the endurance of the void, a new life, a new mode of inexistence and communicative dissemination. Reversing Bazin's characterization, turning it on its head, so to speak, I would propose that cinema may provide modes of inexistence, such as asceticism, with newer dosages of inexistence. Communication, after all, produces communication.

The will to nothingness would betray its own nature, were it to refrain from manufacturing new modalities of nothingness. "Safe Haven" is a masterpiece of abyssal fallenness. Every single body is fallen. The members of the camera crew 
forgot the one fundamental imperative of this demented, sickened fictional hyperreal world: in found-footage cinema, all human participants must die. As I have shown, this former imperative serves to ground the most fundamental level, the noumenal imperative that reads: only the footage may remain. Found footage is a visual simulation of "hypermodernity", a mode of inexistence that makes use of "its own composition in order to place it here, in the real world" (McRobert 141). But what is this "it"? McRobert would have us believe that this "it" is the footage itself. But something more is at work in the realm of "Safe Haven", something infinitely more sinister than any object of media studies. In as much as the real, the reality of negation included, is contained within the frame, there is little danger of negation overflowing through the screen.

Many controversies have resulted from violent films having mimetic effects on filmgoers. If this were the case, the list of films that actually incited paroxysms of violence would be almost endless, and this is almost certainly not the place to attempt an exhaustive review of such films. Instead of a mere sociological fact, I would emphasize the latent real-world agency of "Safe Haven." Startled at the productivity of this unbelievable, occult negation, we as viewers cannot but discover an infernal transference of negativity leading from the imagined cult towards us. The will to nothingness is an intensity situated outside of life, a productivity that persists after vitality has been degraded into the endurance of the void. Even fictional portrayals of the will to nothingness disseminate contents that transform our own thematic fields. Found footage horror introduces new modes of agency into the world, blurring the line between cinema and reality, screen and self. "Safe Haven's" violence is a latent infection, a transgressive production of the will to nothingness. The "it" McRobert cannot seem to be able to name is neither footage, nor media, nor fiction: it is what Nietzsche calls "one of the uncanniest monsters: the 'last will' of man, his will to nothingness" (Nietzsche 122). Within the soul of the viewer, the real is quarantined, selected and degraded into the nullity of the void. We can only hope to spare ourselves from watching what will happen to the many young girls in the sect. Interestingly, they are separated from the other cult members and excluded from the rite of collective suicide. "Ah", we ask ourselves, "what to do with this screaming?"

In this corpselike space, the bumbling, clumsy camera crew becomes a troubling pollution of the screen. We almost wish we could rid ourselves of them, so out of place are these unbelievers, these cynics who do not have the willpower to believe in nothing. They are those who would rather not believe in anything than believe in the nothingness unfolding in front of their eyes. How could the group of Indonesian millenarian true believers decide to collectively put an end to it all? Instead of joining in, and accepting the apparent necessity of belief in nothingness, the crewmembers attempt to escape from their inevitable fates. Comically, almost laughably, they are unaware that they are all characters in a found footage movie, that it is their footage that shall be found, to their own 


\section{IJCS}

considerable detriment. Their work turned out to be their very own unworking (remember the two imperatives? - the camera crew certainly has no inkling of them). The cult-members, through their act of collective suicide conjoin with the logic of horrorific reality in a manner that evades the minds of the cynical Westerners.

The real fails to be contained; "it" intrudes upon the thematic field. But even this "it," this will to nothingness, is composed of multiple themes. While announcing the commencement of the collective suicide, the cult-leader alludes to the "it" that lies in wait, the sweet death that conjoins the body with a state of absolute fallenness: "Father has been waiting for you, we must go to him directly." Subjected in this way to the powers of negation, corporeality attains to the very heart of the religious thematic field, unveiled as being a zone of absolute pollution. The thematic field, even in the case of an "obscure and indistinct" one, "may undergo clarification" (Gurwitsch 353). Intrusion results in a momentary clarification, a fission of content, a specification with preposterous results. Adam, Lena's erstwhile lover, discovers her chained to a bed, a remarkable twist not entirely accounted for in the plot. How did she get there? Was she abducted, or did she assent to this restriction of her freedom? In this state of seclusion, we find the power of fission to be the prelude to a monstrous mystical experience of unity with a creature of absolute impurity. Lena is pregnant with Satan himself, the Father who, in the words of the cult-leader, "virgins, angels, all your desires - He shall provide."

The thematic field is always open to intrusion. "With respect to the intrusion," writes Gurwitsch, "we have the choice of discarding it or yielding to it" (357). Why all this screaming? What to do with this weeping? Rather than accepting the fact of his fatherhood, the joy of having given life to Satan's terrestrial incarnation, Adam screams and proceeds to flee from the scene. An unhuman roar muffles out Lena's screams, who appears to die due to haemorrhagic shock. From her entrails, a black mass emerges, an excess that would certainly be a catastrophic burden for any female body. Refreshingly, the human body in "Safe Haven" is divested of any nostalgic poignancy, or, for that matter, any longing for an unpolluted, pristine identity. That which supervenes is denoted by Gurwitsch as being "intrusive" in relation to the thematic field (350). The intrusion is the traumatic undoing of the thematic field's integrity. Henceforth, the field itself is revealed as pollution, radical impurity and ontological ambiguity.

Who were the intruders in the case of this segment? Lena was pregnant with the devil all along. Her maternal generosity is wasted in giving birth to this penultimate monstrosity. Kristeva's characterization of maternity within patriarchal society is placed in an entirely new light once it is confronted with Lena's monstrous birthing:

harebrained staging of an abortion, of a self-giving birth ever miscarried, endlessly to be renewed, the hope for rebirth is short-circuited by the very 
splitting: the advent of one's own identity demands a law that mutilates, whereas jouissance demands an abjection from which identity becomes absent (Kristeva 54)

Either the law is present, while oppressing and mutilating the feminine, or identity is undone through an enjoyment that tosses subjectivity into Hell. In "Safe Haven", infernality becomes immanent. Through mutilation, the feminine body is unveiled as a neither/nor: neither a mode of self-enjoyment, nor a mode of reproduction, Lena's abject body becomes a conduit for more than human forces. Demonic presence demands the laceration of vulnerable corporeality, for pain is the gate of infernal unbeing. It is Lena's unrealistic desire for a child that leads her to damnation. Adam was correct all along: she should have aborted this infernal thing. But we cannot blame Lena either, for she was caught all along in a web of cultural expectations pertaining to the role of women in sexual reproduction. "It", the "Son", however, in spite of being a newborn, is also the "Father" of this entire setting. The infernal entity, the monster, construes a colony around himself, only to sacrifice it in the process of self-birthing. Lena's corporeal generosity fed into an entity she could never have anticipated, an excess whose arrival in presence proves fatal to her integrity, just as women who reproduce under patriarchy unwittingly contribute to the survival of power structures that feed upon their continued subordination. This arrival, the advent of Satan in the world of found footage horror, is accompanied by the screams of those unable to bear the burden of excessive reality.

Peter Schwenger argues that in screaming "what is at stake here is not the constitution of identity but an attempt to escape it" (Schwenger 383). The screamer is unaware of why he or she screams. Finding its powers, exploring its thematic field, the monstrous theme induces spasms of screaming, infernal bodily shrieks, howls and squeals. Through the gaping, screaming mouth, the future creeps in, the potentiality of disappearance is actualized. Such powers arrive through processes of resemblance (387). Demons are those who have fallen short of nostalgic poignancy. Instead of striving for Heaven, they return to immanence. The cult-leader is wildly successful in his attempt to open the Gate, but little did his followers comprehend that this opening is a fatal laceration of Being itself. After overseeing the birth of Satan within the improbable tropical setting, he literally explodes in ecstasy. Like no other, this scene represents the unrepresentable, the self-destruction of nihilism. Nothingness $=$ God. This Father is a newborn who demands fresh blood. But how did Lena come to be pregnant? One medieval text warns "pregnant women lest they gaze at certain animals (such as apes)", for fear of giving birth to deformed, nonhuman entities that deviate from the human ideal (Elliott 39). "What could Lena have been looking at when fornicating with Adam?" - asks our inner voyeur. Even the relatively technical question of how the monstrosity took root within her womb is left unanswered. 


\section{$48 \quad$ IJCS}

We never learn how or when the lacerating power of nothingness was installed within representation.

The frame cannot contain the poisonous, debilitating content. All those who view the VHS tapes in the $\mathrm{V} / \mathrm{H} / \mathrm{S}$ series disappear or fall victim to a process of melancholic debilitation that invariably ends in suicide. This particular segment is also presented to us as a cheap snuff tape that exerts disastrous consequences upon those who have the temerity to view it. Viewership, in the context of the $\mathrm{V} / \mathrm{H} / \mathrm{S} /$ series, is fatal, and conducive to the spread of soul-destroying ennui. What, if anything, does the monster signify? More to the point, what movements does the emergence of the monstrous theme render possible? In "fusion", claims Noel Carroll, "conflicting themes are yoked together in one", while in "fission", "conflicting themes are distributed (...) among more than one figure" (Carroll 19). In the case of "Safe Haven", we find an original monstrosity. Not only was the site of transgressive religion a place of infernal evil all along, but the bodies of the participants were fused with an absence that seeks to lash out from within the entrails of its host. The newborn Father, not unlike the phallus of psychoanalytic superstition, is "buried in a filthy place, impure, powerful, and aggressive" (20). From within Lena's defiled, filthy place, Satan emerges as an unrepresentable, excessive agent. The will to nothingness is the dirty secret of spirituality, that which must remain hidden within the feminine cave, the filthy, extraterritorial zone, until it is ready to explode, covering the camera in flesh and blood. Carroll oversimplifies things when he equates fission with multiplication, as if only those monsters were capable of fission that reproduced themselves (21). Once born, the monstrous can traverse the realm separating fusion from fission. This transformation, however, leaves the site of original fusion, the womb of presence, empty, hollowed out.

Lena's body becomes wreckage to be disposed of, as sad a fate for femininity as could be imagined. Patriarchy invariably tends to eradicate femininity once it has been exploited to the point of ruination. Instead of sexual affirmation or maternal generosity, Lena never has the opportunity to enjoy her status as sex object, pleased by two men simultaneously, or her new ontological position as the Mother of Evil. Peter Damian presents his readers with a less than flattering, but for all its misogyny, frighteningly entertaining representation of the female consorts who allegedly corrupted men of the cloth:

O you the clerics' charmers, devil's choice tidbits, expellers from paradise, virus of minds, sword of souls, wolfbane to drinkers, poison to companions, material of sinning, occasion of death. You, I say: I mean the female chambers of the ancient enemy, of hoopoes, of screech owls, of night owls, of she-wolves, of bloodsuckers. . . . whores, prostitutes, paramours, wallowing pools of greasy hogs, bed chambers of unclean spirits, nymphs, sirens, lamiae, followers of Diana (Elliott 101). 
The whore, in this context, comes to be equated with the Satanic. Being greasy hogs, presumably insatiable in sexual terms, unclean females become the "devil's choice tidbits." Lena, to use Damian's delightful expression, is at once Satan's "choice tidbit" and his chosen place of origin, as incestual relationship as any. Characteristic of Damian's description is a transgressive fusion of different signs. Markers of animal identity become fused with aspects of human subjectivity and ideas pertaining to moral rectitude (or the lack thereof). Yet this fusion is also the commencement of a process of differentiation. Each fusion of signs, when removed from the misogynistic medieval context, becomes productive of new layers of nothingness, new fissions. One cannot equate fission with purely quantitative multiplication or doubling as Carroll does, for the monstrous intruder may also be summarized as a being that is conducive to unproductive violence, the sacrifice of even the sacrificer himself. The cult-leader who drives his flock to collective suicide, and is then removed through explosion, is a lacerated, failed Father, the "final man", the last nihilist. Reading the figure of the cultist beside Satan, whom he guides to presence, we find that each nihilist is dwarfed by the nothingness he or she wills. The ascetic ideal is a longing to escape from becoming, to become a theme with no field, a "horror of the senses" (Nietzsche 162). Creation, once subjected to the power of negation, is an abandonment of burdens, a dark energy that draws our attention to the periphery. In found footage horror, fear is energized by "elements that rest, respectively, on the periphery and the background of the frame" (Sayad 59). Lena's pregnancy, formerly a marginal element, becomes a central theme that organizes all thematic fields around its nucleus. It is in the sense of being a fleshy, vulnerable body that we find a horrific, elemental factor, a fatal opening within our own being.

Once fully registered, the sense of vulnerability foregrounds itself. With the advent of ruination and the love of nothingness, we realize all of life is an exotic, non-intelligent wasteland. In spite of its ability to self-organize, the inorganic has no relation to intelligibility. While all perception is grounded in a certain environment, this by no means entails the objective meaningfulness of the environment in itself. The sense of dread derives from the horrific feeling that our bodies are prone to laceration. Intruding forces erode our sense of self, the sense of our integrity. Ironically, it is through the senses themselves that an original erosion eats its way into our bodies, rendering the possibility of further experience on our part precarious, open to question. The scream may hence be read as a premonition of the deindividualizing night that slowly creeps into us, gaining a foothold within a rotten interiority. If we accept the idea of transference, an admittedly bold step, but not absurd in the context of a horror film, Lena had to have attained a demonic aspect prior to the shocking birth of her deformed "Son." Her scream is an existential scream, originating from "the sense of anonymous and relentless existence" (Schwenger 389-90). This existence, however, is no longer her own, but a projection of cosmic darkness that was somehow projected 


\section{IJCS}

into her womb by forces outside her control. The filthy phallic seeks after a cave, an impure interiority in which it may gain a footing.

Following the destruction of the motherly body, the frame itself proceeds to melt down into a volcanic substance. By this stage of "Safe Haven", we have already seen the elimination of any documentary film-style distance between observer and observed. In the inside of a thematic field, we cannot maintain our distance from prehended objects. They approach us in their givenness, practically inviting contact through their tangibility. The camera has already been splattered with blood and entrails. After the cult-leader explodes from the thrill of ecstasy, we even see his feces spilled on the floor. These are excessive visions that surely should never have been recorded, and would have been edited out of even the most radical of documentary films. Yet the final excess lies in the visual representation of a hybrid birth, the arrival of a deviant presence that should never have come about. In an unusual angle, we are confronted with the birth of Satan, splitting Lena's belly open, further tainting the camera and all visual representation. Anxiety of one's vulnerability, in this instance of found-footage horror meets body-horror, is mixed, disgustingly, with an "anxiety of the body, the body that insists on existence" (390). Intrusion, in its dense corporeality, insists on existing, even when it should never have been allowed to manifest itself in the realm of immanence. The darkened lighting, along with candles and pendants alluding to the occult, ritualized status of this situation, add to the effect of abyssality. Demonic anonymity is achieved through blood and tears. Below the level of subjectivity, there resides a deeper scream, an existential scream that is no longer human, a scream that cannot be reintegrated into the circuits of human society. Edvard Munch summarizes his motivation for painting his masterpiece, The Scream, in the following, breathtaking sentences:

I was walking along the road with two friends. The sun set. I felt a tinge of melancholy. Suddenly the sky became a bloody red. I stopped, leaned against the railing, dead tired and I looked at the flaming clouds that hung like blood and a sword over the blue-black fjord and city. My friends walked on. I stood there, trembling with fright. And I felt a loud, unending scream piercing nature (390-1).

Lena's and Adam's screams are indicative of a fundamental fission, the unleashing of forces within a decomposing thematic field. Once Satan's advent is announced, the cult compound becomes a factory of death. Decomposition leaves no space for domesticity or human reproduction. Adam, Malik and Lena prove to be the members of a doomed love triangle, united by nothing except despair and anguish. If only she had chosen abortion... Horrifyingly, we realize that the cultist was correct all along: there really are multiple "orders of existence" (Gurwitsch 372). Not only subtraction but also multiplication, when taken to extremes, can be productive of horror. When we identify too many orders of existence, levels of 


\section{Lovasz 51}

the world that should not exist or cannot, under the present laws of physics, make themselves present, then we find ourselves in a situation of additive horror. Excessive orders are multiplicities, groupings of objects that present themselves to pretheoretical experience through the penetration and dessication of prior expectations.

No knowledge, not even a theological background, may prepare us for the deluge of reality as it presents itself to our pretheoretical awareness in "Safe Haven." Nothing they knew could have prepared the camera crew for what lay in store for them. In this bloody antechamber, the beast roars. The whiteness of the light - outside, the sun is shining - is replaced by an ever more bloody red light. But as Munch reminds us, for the discerning eye, the Sun presents itself in a blood red hue. When they tore out the hearts of their sacrificial victims, the Aztec priests knew this. When a Mexican gang member tears out the heart of her rival, she knows this. It is only the outsiders, the intruders, who view the Sun as something benign, something that gives without demanding anything in return. In truth, the gift demands the eternal return of organic materials, blood and lives. Bearing witness to this bloody enlightenment, inside and outside melt into one. However bright the sunlit outside may seem, it too is a blood red sky, an awful vision that assailed Munch on that infernal day. Pierced by the scream of nature subjected to the tyranny of the Sun, we too realize that the orders of existence are multiple and cannot be reduced to our presence.

Even the past cannot be said to evaporate without consequences. "In fact", asserts Gurwitsch, "every segment of our past is an order of existence" (375). Experience and the thematic field alike are torn apart by nuclear fission, introduced by an outside that is inarticulable, unassimilable. Solar energy is an excess that explodes into us through its manifold rays. In addition to orders of existence, we find in "Safe Haven" a fission of representation. Not all forms of vision are meant to survive. There is a hidden connection between the cameras and the demonic, for we are given the impression that the proliferation of demonic forces being raised within the compound seems to have infected the camera's batteries. Could the demon be interpreted as the "succubus" of visual media? In spite of the fact that "orphaned media is not to be trusted" (Benson-Allott 179), the assertion that media is, in and of itself evil, would be quite a stretch. It is an exaggeration to claim that the camera is demonic. It would suffice to say that media are more than mere tools; they are agencies that enact themselves with the assistance of their surroundings, almost like animals, with the important exception that the level of self-organization of technological media, at least presently, is far inferior to that of living organisms. This is what makes "Safe Haven" and most of the other segments in the $\mathrm{V} / \mathrm{H} / \mathrm{S} /$ series remarkably realistic: for the most part, the cameras portrayed in the series behave in a believable manner. It is an overstatement to claim, as Caetlin Benson-Allott does, that audience reactions to found footage horror films are "responses to the medium itself" (189). Within the 


\section{IJCS}

thematic field captured by "Safe Haven", disjunctions and reactions are internal to the multiplicity of horrible forms themselves.

Without a channel, a medium through which demonic infection may proceed, we would of course never experience this monstrous birthing in quite the same manner. Thematic fields come into contact with us through mediated events. But once the viewers have been selected and successfully infected by ennui, the will to nothingness may infect its subjects, only to abandon them after having parasitized their inner contents. Once appeased by the self-sacrifice of the cultists, Satan has no use for their abject bodies. Their blood continues to stream upon the walls and floors, or, to use a wordplay, stream upon screens that stream the film in online form, but Satan flies away into the nothingness of the sky. While the followers of the demon fade away into death, a new conjunction is revealed: the correlation of the demonic and the aerial. Any sacred act, be it a consecration or a defilement, is a fusion of two orders of existence, the pure and the impure. As Damian stresses, in the moment of consecration "the sky is opened, the highest and the lowest things rush together in one" (Elliott 106).

Sure enough, Satan, once released from Lena's impure place, enjoys his newfound freedom, and takes flight. Once human presence has been gutted, rendered inoperative, the demonic, the lowest of all the orders, may proceed upon its celestial voyage to some faraway place, perhaps Heaven itself, or a volcanic Paradise of geological flows... In the final scene, however, one final fusion awaits: that of Father with Son. Adam, it turns out, survives the entire ordeal, and desperately attempts to escape in the crew's van. But Satan catches up with him. Jumping over humanity, Satan lifts up Adam, who breaks out in laughter. This laughter, I submit, is of a similar character to that of the existential scream described by Schwenger and vividly conveyed by Munch.

Laughter and the scream, once they have attained the level of inexistential anguish, once existence pours into its own internal disjunctions, is an emanation of dread, flowing "out of a face that has now become meat" (Schwenger 392). Adam laughs, not because he enjoys his obscure fate, but rather, he has realized that he has become anonymous meat, flesh that will most probably be burned in Hell by Satan's minions. This is an infernal laughter, informed by a forgetting of self. Tactility returns, only to be blindly abandoned. While Adam laughs, his evil progeny reminds him of his fatherhood. Adam cannot remain a distant, estranged father who has abandoned his Son. Rather, he is the God who must confront the deformed failure that is his creation. Laughter is the product of an abyssal, divine realization. Unable to enlighten this cosmos, God can do nothing more than laugh his way into inexistence. There is no need for us to visualize Adam's final fate, for we know all too well what lies in store for him. Adam becomes a God murdered by his own solitude.

The final destination is none other than the desert of inexistence. The resolute say "no" and make way for the desert (Nietzsche 107). Could Adam's laughter be this "no", this resolute rejection of life and the shallowness of Being? By now, 
only four themes are intact: the footage, Adam and Satan, as well as the fatherhood that connects Adam with Satan. As opposed to the Christian "Mother of God", Adam is a Mary with a penis, father to the Antichrist. At this stage, visual representation cannot enlighten us. Representation can only go so far. Singularity stands opposed to any form of reproduction, visual or otherwise. The singular experience of exiting the scene, and returning to a volcanic reversed-Paradise, replete with magma flows, cannot involve words, gestures or images. Rather, it involves a tactility implicated in the breaching of all subjectivity. Adam laughs because he feels himself already slipping into maddened self-abandonment. Behind his laughter, we find a fervent NO to life, but also an affirmation, a YES to abandonment. His lover dead, his career ruined, Adam has no choice but to abandon his will and accept the final consequence of transgressive religiosity. Adam laughs because he has been forced into a complete negation he never assented to. Once abducted by Satan, Adam merges with a polluted, sickened violet sky. Only the footage remains.

\section{Works Cited}

Bazin, Andre. What is Cinema? Volume 1. Translated and selected by Hugh Gray. University of California Press. 2005.

Benson-Allott, Caetlin. Killer Tapes and Shattered Screens. Video Spectatorship from VHS to

File Sharing. University of California Press, 2013.

Carroll, Noel. "Nightmare and the horror film: the symbolic biology of fantastic beings." Film

Quarterly 34.3, 1981, pp 16-25.

Deleuze, Gilles. Nietzsche and Philosophy. 1962. Translated by Hugh Tomlinson. Columbia University Press, 1983.

Elliott, Dyan. Fallen Bodies. Pollution, Sexuality, and Demonology in the Middle Ages.

University of Pennsylvania Press, 1999.

Gurwitsch, Aron. The Collected Works of Aron Gurwitsch (1901-1973). Volume III. The Field

of Consciousness: Theme, Thematic Field, and Margin. Edited by Richard M. Zaner and Lester Embree. Spriner, 2010

Kristeva, Julia. Powers of Horror. An Essay on Abjection. 1980. Translated by Leon S.

Roudiez. Columbia University Press, 1982.

McRobert, Neil. "Mimesis of Media: Found Footage Cinema and the Horror of the

Real." Gothic Studies 17.2, 2015, pp 137-150. 


\section{IJCS}

Nietzsche, Friedrich. On the Genealogy of Morals. 1887. Translated by Walter Kaufman and

R. J, Hollingdale. Vintage Books, 1989.

Reyes, Xavier Aldana. "Reel Evil: A Critical Reassessment of Found Footage Horror." Gothic

Studies 17.2, 2015, pp 122-136.

Rødje, Kjetl. "Intra-Diegetic Cameras as Cinematic Actor Assemblages in Found Footage

Horror Cinema." Film-Philosophy 21.2, 2017, pp 206-222.

Said, Edward W. Orientalism. Pantheon Books, 1978.

Sayad, Cecilia. "Found-Footage Horror and the Frame's Undoing." Cinema Journal 55.2, 2016, pp 43-66.

Schwenger, Peter. "Phenomenology of the Scream." Critical Inquiry 40.2, 2014, pp 382-395.

Williams, Evan Calder. "Sunset with Chainsaw." Film Quarterly 64.4, 2011, pp 28-33. 